\title{
CT visualising infective vegetation
}

\author{
Hideharu Hagiya, Kou Hasegawa, Kikuko Asano, Fumio Otsuka
}

Department of General Medicine, Okayama University Graduate School of Medicine, Dentistry and Pharmaceutical Sciences, Okayama, Japan

\section{Correspondence to}

Dr Hideharu Hagiya,

e_dai_for_all@hotmail.com

Accepted 17 November 2014

\section{DESCRIPTION}

A 34-year-old man with a history of five cardiac operations including an operation for construction of a right ventricular outflow tract (RVOT) with a homograft due to extreme tetralogy of Fallot suffered from persistent fever. With positive blood culture (methicillin-sensitive Staphylococcus aureus) and multiple septic pulmonary emboli shown by CT, right-sided infective endocarditis (IE) was suspected. Transthoracic and transoesophageal echocardiograms were subsequently obtained but did not depict any pathogenic lesions. However, a contrast-enhanced CT scan of the heart successfully revealed a defect of contrast media at the RVOT (figure 1A), which was not seen in a previous CT scan. Fluorodeoxyglucose positron emission tomography (FDG-PET) demonstrated a high uptake at the corresponding site (figure 1B). Under a diagnosis of right-sided IE, antibiotic therapy was initiated. After 8 weeks, although the patient's condition improved and serum inflammatory markers were all within normal ranges, the lesion had not disappeared (figure 1C) and cardiac surgery was eventually performed. It was confirmed that the vegetation remained and replacement of the RVOT was performed.

Echocardiography is a gold standard method to visualise infective vegetation, but it failed in this case. The patient's history of repeated cardiac surgery might have been a main reason for the negative results of echocardiography. Utility of FDG-PET for the evaluation of IE has been reported $;{ }^{1-3}$ however, utility of contrast-enhanced CT has not been established. The present case shows that a contrast-enhanced CT scan of the heart may be an alternative method for uncovering infective vegetation, especially in patients with previous cardiac surgery.

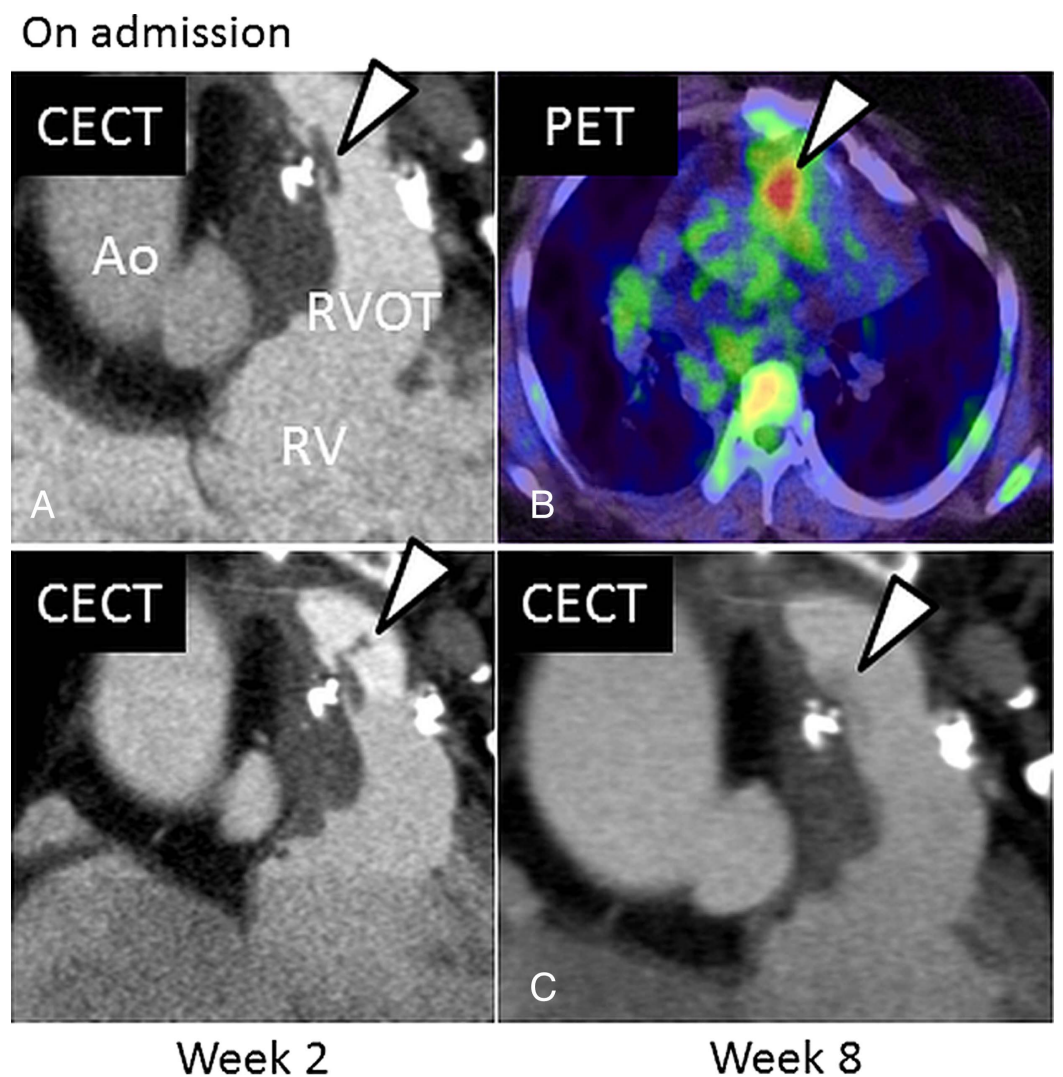


Learning points

In patients with previous cardiac surgery, visualisation of infective vegetation can be challenging because of anatomical abnormality.

- Even if echocardiography fails, contrast-enhanced CT can be alternatively used for visualising infective vegetation.
Patient consent Obtained.

Provenance and peer review Not commissioned; externally peer reviewed.

\section{REFERENCES}

1 Yeh CL, Liou JY, Chen SW, et al. Infective endocarditis detected by (18) F-fluoro-2-deoxy-D-glucose positron emission tomography/computed tomography in a patient with occult infection. Kaohsiung J Med Sci 2011;27:528-31.

2 Klaipetch A, Manabe 0, Oyama-Manabe N, et al. Cardiac (18)F-FDG PET/CT with heparin detects infective vegetation in a patient with mechanical valve replacement. Clin Nucl Med 2012;37:1184-5.

3 Gouriet F, Bayle S, Le Dolley Y, et al. Infectious endocarditis detected by PET/CT in a patient with a prosthetic knee infection: case report and review of the literature. Scand J Infect Dis 2013;45:570-4.

Competing interests None.

Copyright 2014 BMJ Publishing Group. All rights reserved. For permission to reuse any of this content visit http://group.bmj.com/group/rights-licensing/permissions.

BMJ Case Report Fellows may re-use this article for personal use and teaching without any further permission.

Become a Fellow of BMJ Case Reports today and you can:

- Submit as many cases as you like

- Enjoy fast sympathetic peer review and rapid publication of accepted articles

- Access all the published articles

- Re-use any of the published material for personal use and teaching without further permission

For information on Institutional Fellowships contact consortiasales@bmjgroup.com

Visit casereports.bmj.com for more articles like this and to become a Fellow 